and took up the Scottish appointment in 1930. At Beckenham he was associated with Prof. Dalling, and other workers in those laboratories, in the production of biological products, and particularly in investigations of anaerobic infections in sheep. In Scotland he has led a team of workers in investigating and dealing with certain sheep diseases, notably louping-ill, tick-borne fever, braxy and lamb dysentery.

At the time of Gordon's appointment, the causal agent of louping-ill had just been discovered at the Edinburgh institute. Dr. Gordon followed up this work, making a close study of the disease and of the filtrable virus responsible for it, and developed methods for the immunization of sheep against the infection. An early discovery in this later work was that two entirely different virus infections were associated with louping-ill, that due to the true louping-ill virus and another, hitherto not recognized, that was named the virus of tick-borne fever, the latter infection being in itself a less severe disease. Among other disease problems on which he has worked in Scotland is grass sickness in horses, and although the cause of the disease is still unknown he has made notable contributions to the literature on the subject. Dr. Gordon has been active in a wide range of veterinary activities in Scotland and has a close personal interest in, and a practical experience of, general farming.

\section{Dr. W. E. Gaunt}

Dr. W. E. GaUnT has been appointed research director of the Ashe group of associated companies. Dr. Gaunt graduated from the Colour Chemistry Department at the University of Leeds and obtained his Ph.D. for work on biochemistry and physiology undertaken at the Leeds School of Medicine. Afterwards Dr. Gaunt joined Sir John Orr's staff at the Rowett Research Institute to work on nutrition problems, and just before the War went to Guy's Hospital Medical Schocl as dental research fellow to do work of a similar nature. Since the War started Dr. Gaunt has gained further experience in organic chemistry at Guy's, working with Prof. C. S. Gibson, and has also increased his all-round knowledge of nutrition during a short spell with Imperial Chemical Industries Ltd. Dr. Gaunt's experience in several research fields will enable him to serve Messrs. Ashe Laboratories Ltd. in maintaining and extending on sound nutrition lines their numerous food products. We understand that Dr. Gaunt will be encouraged to continue work on fundamental problems, particularly on human protein requirements.

\section{Newton as an Astrophysicist}

A PAPER by Elizabeth Connor entitled "Sir Isaac Newton, the Pioneer of Astrophysies" appears as Leaflet No. 158 of the Astronomical Society of the Pacific (April 1942), which supplies a brief outline of the life and work of Newton. Up to the time of entering the University of Cambridge, Newton had not exhibited any extraordinary talent, and though his undergraduate days were profitable, those which followed immediately after he graduated were the most productive which any scientific worker ever experienced. The outbreak of the plague forced him to leave Cambridge, and practically all his time between August 1665 and March 1667 was spent at Woolsthorpe, where his exile allowed him to concentrate on some of his greatest achievements. Among these may be noticed his method of fluxions, the law of the composition of light, and the law of universal gravitation. During this period he gave attention to experiments with the refracting telescope, but because he believed that chromatic and spherical aberration could not be overcome, he turned his attention to the reflecting type.

Towards the end of 1668 Newton completed his first telescope with an aperture of a little more than an inch and a tube 6 in. long. His second telescope was exhibited at the Royal Society in 1672 and is still in the possession of the Society. Its principle was used as the model and forerunner of a succession of giant telescopes which have been constructed since the days of Newton and are still the astrophysicist's best tool. His "Principia" did not appear until 1687 and his real scientific career ended with its completion. Most of his later years were spent in London as Master of the Mint, and he had many honours bestowed on hirn, but there was no return of the originality of his earlier days. Nevertheless, he gave a considerable amount of time to working over the material in hand. In 1704 his "Optics" appeared and in 1713 and 1726 the second and third editions of the "Principia". Specialists in various branches of science still voice the debt of their sciences to Newton.

\section{Benedict Dybowski}

Among the Poles whose scientific work was conducted in and for Russia was Benedict Dybowski, a sketch of whose life is given by Dr. J. Borucki in the first issue of Polish Science and Learning (June, 1942 : Oxford University Press. 2s. 6d.). Dybowski was born at Minsk in 1833. As a schoolboy he kept various animals and was apparently the first to observe the metamorphosis of Petromyzon. $\mathrm{He}$ studied medicine and biology at Dorpat (1856), Breslau (1857) and Berlin (1860), where he published minor researches, for example, on artificial insemina. tion of bees. At Dorpat again, in 1861, he worked on a monograph of the fishes of the Baltic lands. However, he was arrested for his political beliefs, and though the sentence of deportation was at first revoked, he was sent to Siberia after the 1863 insurrection. Here he began by exploring the forest and steppe around Czyta. Later, at Kultuk, he made long journeys to the Saya Mountains and to Chamar, developing a vast philanthropic medical service among the native population, so that the governor, J. G. Skolkow, invited him to join an expedition to the tributaries of the Amur and Ussuri Rivers, penetrating as far as the Pacific. They had scanty means, having to make their own boats. Nevertheless, Dybowski sent extensive collections to European museums and developed a view that each region showed a special structure of animal life in close correspondence with the environment. He discovered a number of hitherto unrecorded species, including a deer on the Ussuri, and noted the differences between Siberian and Bengal tigers. The birds he collected provided the basis for Taczanowski's critical "Review of Siberian Ornithological Fauna".

With Godlewski, Dybowski spent several years studying the fauna of Lake Baikal, and his researches included biological, chemical, bathymetric and temperature observations. The molluscs and sponges collected at this time were later described in a classical monograph by Benedict's brother, Wladislaw. Dybowski's extensive researches had enabled his 